\title{
ANTARCTIC CLAIMS-DIPLOMATIC EXCHANGES BETWEEN GREAT BRITAIN, ARGENTINA AND CHILE IN 1951
}

Earlier diplomatic exchanges of 1947 and 1948 were published in the Polar Record, Vol. 5, Nos. 35/36, 1948, p. 228-40. The notes published below continue the series relating to this territorial dispute. The texts were made available in the library of the House of Commons by the Under-Secretary of State for Foreign Affairs (Mr Ernest Davies) in reponse to a parliamentary question by Major Tufton Beamish on 2 July 1951 (see Hansard of that date). The texts of all earlier British protests to Argentina and Chile concerning violations of United Kingdom Antarctic territory, together with the replies received (1943-51), were made available at the same time. Both Argentina and Chile have established additional meteorological stations in the Falkland Islands Dependencies, and both countries continue to reject the British proposal to submit this dispute for arbitration by the International Court of Justice at the Hague.]

ARGENTINA

Sir Henry Mack to Dr Paz*

No. 180

British Embassy

Buenos Aires

30th April 1951

Monsieur le Ministre,

On 3rd January and 17th and 23rd December 1947, Sir R. Leeper, on instructions from His Majesty's Principal Secretary of State for Foreign Affairs, communicated to your Excellency's Government notes which formally refuted Argentine claims to sovereignty over certain British territories in the Falkland Islands Dependencies and realfirmed British sovereignty over the whole area. His Majesty's Government have noted with concern that, notwithstanding, Argentine acts of trespass in this area have continued unabated. In particular, the master of the British relief ship John Biscoe has recently reported the establishment of an Argentine post in Paradise Harbour off the Danco Coast of west Graham Land. The master of the John Biscoe, acting on the authority of the Governor of the Falkland Islands and its Dependencies, has presented a formal note of protest to the commander of the Argentine flotilla. Since then the Argentine Government has announced the establishment of another base, to be named General San Martin, which is understood to be in Marguerite Bay. These posts are in addition to those already illegally maintained by the Argentine Government elsewhere in the Falkland Islands Dependencies, which have been the subject of earlier protests.

2. The sovereignty of His Majesty's Government in the Falkland Islands Dependencies rests on the accepted principles of international law, for the reasons set out in earlier notes addressed to the Argentine Government, in particular Sir R. Leeper's notes of 3rd January 1947, and his notes of 17th and 23rd December 1947, referred to above. These communications indicated that the Argentine claim to sovereignty over any part of the British Antarctic territory are unfounded, and the British title to this area, known as the Falkland Islands Dependencies, is based on rights acquired by virtue of discovery, on the issue of the Letters Patent of 21st July 1908, and 28th March 1917, and on the measures taken by His Majesty's Government for the necessary administration of these British territories.

3. The action of the Argentine Government in landing parties in Paradise Harbour and, it is understood, in Marguerite Bay, and erecting installations there, without seeking permission or making prior arrangements with the competent British administrative authorities, is an infringement of His Majesty's Government's

* Argentine Minister for Foreign Affairs.-Eds. 
territorial rights. I have, therefore, been instructed to record a formal protest on behalf of His Majesty's Government against the establishment of these unauthorised Argentine posts in territory where His Majesty's Government's title is well established and generally recognised.

4. I am to add that, if the Argentine Government are unwilling to recognise the validity of His Majesty's Government's title to the Falkland Islands Dependencies, the case seems to be one in which, in the interests of the peaceful settlement of disputes in respect for international law, the jurisdiction of the International Court of Justice at The Hague should be invoked. His Majesty's Government, for their part, once more declare their desire to settle such differences of opinion in a spirit of amity; and they accordingly reaffirm their willingness to accept the jurisdiction of the court and to abide by its decision.

I avail myself, \&c.

[Signed] HeNry B. MaCK

\section{Translation of Note from Dr Paz to Sir Henry Mack}

D.P.

D.A.M. (No. 876)

Buenos Arres,

1st June, 1951

Your Excellency,

I have the honour to acknowledge the receipt of your Excellency's note No. 180 of 30th April last, in which you refer to the establishment of two new Argentine bases in Antarctica and in which you make a formal protest in the name of your Government on the grounds that these bases gave been established in British territory.

The above-mentioncd note refers to:

(1) Previous communications from the embassy.

(2) The recent Argentine activities.

(3) The rights which the British Government invoke.

(4) 'The protest which the British Government make in respect of the establishment of the two new Argentine bases.

(5) The offer to accept the jurisdiction of the International Court of Justice.

1. Your Excellency mentions the notes sent to this . Ministry by the British Embassy dated 3rd January and 17th and 23rd December 1947, which set out grounds on which the British Government consider that their rights to certain regions such as the Island of South Georgia, the South Sandwich Islands and the Argentine sector of Antarctica are based.

This Ministry answered the communications of the British Embassy in notes dated 15th February 1947, and 28th January 1948. In these notes the views of my Government concerning this problem were set out; the claims put forward were then rejected, as they are now, in every particular, and the sovereignty of the republic was reaffirmed over the territories to which reference was made.

2. Your Excellency states that His Majesty's Government have noted with concern that acts of trespass on the part of the Argentine authorities have been repeated in the area in question. You mention, in particular, the two new bases recently established at Punta Proa in Paradise Harbour and at Marguerite Bay, and add that in respect of the former, the captain of the British ship John Biscoe presented a protest in the name of the so-called "Governor of the Falkland Islands (Malvinas) and their Dependencies" to the commander of the Argentine navy tug Sanaviron.

The islands of South Georgia, the South Sandwich Islands and the Argentine sector of Antarctica are subject to our sovereignty and no one is therefore allowed to exercise any authority within these territories without the permission of the Argentine Government. 
The reply of the commander of the Sanutiron, which rejects the above-mentioned protest, is based, in fact, on the exercise of Argentine rights over Argentine territory.

3. In paragraph 2 of your note, it is stated that the British title to this area is founded on rights acquired by virtue of discovery, on the issue of the Letters Patent of 21st July 1908, and 28th March 1917, and on the measures taken by His Majesty's Government for the administration of these territories. In this connexion, your Excellency's attention is called to the fact that discovery unaccompanied by effective occupation does not afford a basis in international law for any right to sovereignty and is invalid in the face of legitimate titles of a juridical, historical and geographical character, which the Argentine Republic possesses. To these titles can be added the fact that Argentina has been in effective occupation of the above-mentioned regions for the past fifty years.

The claim to have confirmed the rights conferred by the discovery by means of unilateral declaration, such as the Letters Patent of 21st July 1008, and 28th March 1917, which are administrative acts of a domestic character, cannot alter the true state of affairs, nor modify the recognised principles of international law. For these reasons the Argentine Government do not admit that any right to sovereignty derives from the above-mentioned Letters Patent.

$\Lambda$ segards the measures which your Excellency states the British Government have taken for the administration of the territories concerned, it is observed that these measures have no legal force whatever. 'They have been illegally taken in areas which form a part of the territorial heritage of the Argentine nation, which has exercised its sovereignty by means of intensive activity, such as the continuous operation since 1904 of the Meteorological Observatory in the South Orkney Islands, the constant voyages and operations of the Argentine navy, the establishment of bases and telegraph ollices, scientific activities of world-wide importance, and, in addition, numerous acts of the Government, which demonstrate clearly the effectiveness of the authority exercised by the republic over this part of its territory.

As regards the words "Falkland Islands Dependencics" which the British Government use, this Ministry has already had occasion to inform the Embassy that they are unacceptable; the Malvinas Islands are Argentine, and the action of the republic in order to secure the restoration of this part of its territory has been, is, and will be continuous and is an objective the pursuit of which they will not abandon until these islands form without any reservation a part of the territory of the republic.

Furthermore, this Ministry expressed similar views to the Embassy in respect of the titles quoted by the British Government as the basis for their claims to sovereignty in Antarctica, in the above-mentioned notes of 15th February 1947, and 28 th January 1048, the terms of which I take this opportunity to reallirm.

4. In paragraph 3 of your note, your Excellency made a formal protest in the name of His Majesty's Government against the establishment of two Argentine posts.

The Admiral Brown naval post and the General San Martin base are established in Argentine territory and there is no need for permission or authority from any other country to set them up. For this reason the Argentine Government consider that the protest made by the British Government is unfounded and are obliged to reject it completely.

For their part, my Government regard as acts violating their sovereignty the unauthorised British administration, establishments, scientific and exploratory expeditions in the Falkland Islands (Isles Malvinas), South Georgia, the South Sandwich Islands and the Argentine sector of Antarctica, which is situated between longitude $25^{\circ}$ and $74^{\circ}$ West of Greenwich, south of latitude $60^{\circ}$ South, and for this reason expressly reserve their rights to exercise Argentine national authority within the boundaries of their territorial possessions.

5. Finally, your Excellency renews the offer to submit the case to the jurisdiction 
of the International Court of Justice at The Hague, and, in a friendly spirit, repeats your desire to resolve this difference of opinion.

In this connexion, my Government, in conformity with the views expressed to the embassy on previous occasions, reaffirm that the republic exercises de jure and de facto sovereignty over its sector of Antarctica. For this reason, it cannot submit to the decision of an international body territories which legitimately belong to it and of which it is in effective occupation.

Apart from this, I share the view set out in your Excellency's note regarding the peaceful settlement of disputes in respect for international law. In this spirit, my Government, inspired by the same objectives as are mentioned in your Excellency's note, are disposed to consider problems which may arise in the spirit of amity which is characteristic of the relations between our two countries.

I avail myself, \&c. [Signed] Jesús Hirólito Paz

\section{CHILE}

Sir B. Jerram to Señor don Benjamin Claro Velasco*

No. 10

Britisir Embassy, Santiago, 3rd April 1951

Your Excellency,

On 17 th December 1947, and 1st March 1948, Mr Leche, on instructions from His Majesty's Principal Secretary of State for Foreign Affairs, communicated to your Excellency's Government Notes which formally refuted Chilean claims to sovereignty over certain British territories in the Falkland Islands Dependencies and reallirmed British sovereignty over the whole area. His Majesty's Government have noted with concern that, notwithstanding, Chilean acts of trespass in this area have continued unabated. In particular, the master of the British relief ship John Biscoe has reported the establishment of a Chilcan post on Penguin Island in Paradise I-Iarbour off the Danco coast of west Graham Land. This is in addition to the Chilean posts already illegally maintained on Greenwich Island and at Cape Legoupil, which have been the subject of carlier protests. The master of the Jolln Biscoe, acting on the authority of the Governor of the Falkland Islands and its Dependencies, has presented a formal note of protest to the commander of the Chilean flotilla.

2. The sovercignty of His Majesty's Government in the Falkland Islands Dependencies rests on the accepted principles of international law for the reasons set out in earlier notes addressed to the Chilean Government; in particular, the Prime Minister's Note of 11 th November 1946, to the Chilean Ambassador in London and my predecessor's Note of 17 th December 1947. These communications indicated that the Chilean claims to sovereignty over any part of the British Antarctic territory are unfounded; and that the British title to this area, is based on rights acquired by virtue of discovery, on the issue of the Letters Patent of 21 st July 1908 and 28th March 1917, and on the measures taken by His Majesty's Government for the necessary administration of these British territories.

3. The action of the Chilean Government in landing a party on Penguin Island and erecting a post there, without seeking permission or making prior arrangements with the competent British Administrative authorities, is an infringement of His Majesty's Government's territorial rights. I have, therefore, been instructed to record a formal protest on behalf of His Majesty's Government against the establish-

* Chilean Minister for Foreign Affairs.-Eds. 
ment of this unauthorised Chilean post in territory where His Majesty's Government's title is well established and generally recognised.

4. I am to add that, if the Chilean Government are unwilling to recognise the validity of His Majesty's Government's title to the Falkland Islands Dependencies, the case seems to be one in which, in the interests of the peaceful settlement of disputes and in respect of international law, the jurisdiction of the International Court of Justice of The Hague should be invoked. His Majesty's Government for their part once more declare their desire to settle such differences of opinion in a spirit of amity and they accordingly reaffirm their willingness to accept the jurisdiction of the court and to abide by its decision.

I avail myself, \&c.

[Signed] C. B. Jerram

\section{Translation of Note from Señor don Benjamin Claro Velasco to Sir B. Jerram}

No. 04514

SanTiago, 17th May 1951

\section{Your Excellency,}

I have the honour to refer to your Excellency's Note No. 10 of 3rd April stating that His Britannic Majesty's Government has noted with concern Chilean acts which it regards as of trespass in the zone termed Falkland Islands Dependencies. In particular, your Excellency refers to the fact that the captain of the British ship Joln Biscoe has reported to his Government the establishment of a Chilean post on Penguin Island in Paradise Harbour off the Danco coast in O'Higgins Land,* and that the captain of the John Biscoe acting on the authority of the Governor of the Falkland Islands and its so-called Dependencies presented a formal note of protest to the commander of the Chilcan flotilla which was operating in the Antaretic vaters of the republic.

2. Your Excellency further summarises the titles of sovereignty which in the opinion of your Government your country could excrcise over this region, to reach the conclusion that the steps taken by the Chilcan Government in establishing a base on Penguin Island without asking permission or making prior arrangements with the competent British administrative authorities is an infringement of the territorial rights of Great Britain and consequently records a formal protest against the establishment of this Chilean base in territory which His Majesty's Government regards as British.

3. Your Excellency adds that if the Chilean Government is not disposed to recognise the British titles to what it calls the Falkland Islands Dependencies the case would seem to be one in which the jurisdiction of the International Court of Justice should be invoked. In this respect His Britannic Majesty's Government dcclares once more its desire to settle such differences of opinion in a spirit of amity and reafirms its proposal to accept the jurisdiction of the Court and to abide by its decision.

4. In reply, I beg to inform your Excellency that the Chilean Government regards as entirely lacking in foundation the protest alluded to, presented by the captain of the British ship Joln Biscoe to the commander of the Chilean flotilla operating in Chilean Antarctic waters and which was categorically rejected by the latter, as also the protest presented by your Excellency in the note under reference, against the erection and maintenance of a Chilean base on Penguin Island, Paradise Harbour, off the Danco coast in O'Higgins Land, as this concerns acts carried out within the limits of the jurisdiction of the republic and in the exercise of our sovereignty.

* The Chilean name for Graham Land.-Eds. 
5. My Government has already had occasion to point out to your Excellency that it regards O'Higgins Land, the South Shetland Islands and other archipelagos of that region, as integral parts of the national territory in virtue of titles which it regards as definite and indisputable. It follows that the rights which His Britannic Majesty's Government claims in the notes of 11 th November 1946, 17th December 1947, and in that of 3rd April of the present year, to which I am referring, based upon discovery, the issue of letters patent of 21st July 1908, and 28th March 1917, and on the measures which that Government states it has taken for the administration of those territories, cannot be accepted by my Government.

6. In fact discovery and the scientific expeditions carried out in the Antarctic do not and cannot constitute any title over this region. Such acts do not confer of themselves any right of sovereignty and it cannot be seen how they could create. such a right in a region which forms part of the national territory of another State and over which Chile exercises, and has exercised, full sovereignty.

7. Moreover, the Government of Chile maintains its view in recognising no force or legal effect in the Letters Patent of 21st July 1908, and 28th March 1917, by which your Excellency's Government declared that a great part of the territory of my country belonged to it.

8. 'Thus the acts of administration that your Excellency's Government states to have been carried out in the Antarctic region have been effected without the consent or authorisation of my Government, and in no way affect the valid Chilean titles in that zone over which the Government of Chile from the beginning of the present century has been exercising a permanent administration, complying thus with its obligations as a sovereign State in a territory which belongs to it.

9. In consequence, the Government of Chile finds itself bound to reject the protest contained in the note under reference, in the same form and for the same reasons already indicated in notes 5208 of 16 th May 1947, and 1036 of 31 st January 1948 by which earlier protests were duly rejected, and to ratify the act of the commander of the Chilean Antarctic flotilla, who in his turn categorically rejected the protest of the captain of the Jolen Biscoe, pointing out at the same time that the said British vessel was in Chilean territorial waters without our authorisation which constituted a clear violation of the territory of the republic.

10. My country las always supported the principle of submitting to international jurisdiction or to arbitration controversies which may arise of a legal nature, and enjoys in this respect an honourable tradition which few countrics can display with more pride, but my Government cannot share the view of the Government of Great Britain that the matter of your Excellency's note should be submitted to the International Court of Justice, for this matter is one concerning our territory and that would imply submitting our own national sovereignty to the judgment of third parties. What is more, this would not be an effective solution since there are multilateral claims over the same region, some of which Chile could in no wise accept nor probably Great Britain either.

11. Finally, your Excellency, I must add that my Government greatly appreciates the traditional bonds of friendship which unite our two peoples, unchangeable bonds which have been translated into innumerable forms of co-operation and good understanding, and it is certain that the close collaboration with British scientific or exploratory expeditions which may be sent to Chilean Antarctic territory will make it possible, and particularly agreeable, that our two countries should meet in the future participating in mutual labours with evident benefit for that class of investigations of general interest.

I avail myself, \&c.

[Signed] H. WaLFer LaRraiN 